\title{
EMERGING TRENDS AND RECENT DEVELOPMENTS IN EDUCATION RESEARCH Catalina ULRICH*
}

\section{Abstract}

This article reports an analysis on methodological and thematic trends in the field of educational research. The introduction presents main challenges regarding recent insights and pressure for research in universities as well as main objectives. Theoretical framework section reflects actual debates regarding educational research within the social science area and under pressure of public accountability and funding in European Union universities and US. Next section describes data sources and processing, using mainly content analysis on three largest research networks: AERA (founded in 1916), EERA (founded in 1994) and WERA (founded in 2009). Comparative analysis provides interesting information regarding the history, missions, priorities, principles and regulations on carrying educational research. One the one hand, there are noticeable differences in time gap, practice-orientation, social responsibility and funding policies for university research in Europe and US. On the other hand, EU's struggle in competition with US puts pressure on education researchers; university ranking and impact evaluation are seen as external and mainly originated in US tradition. Findings about the dynamics of research networks, problem-driven and contextual sensitive approach, integrated research endeavour (inter and trans-disciplinary), teams flexibility and emerging interests could have a double impact. It could inspire ongoing efforts of redesigning the doctoral studies programs at the University of Bucharest and also the $\mathrm{PhD}$ students' identity and career building occurring in real institutions and academic sphere.

Key words: network, methodology, phronesis, policy, scientifically based research

\section{Introduction}

During the last decades, education became one of the most visible issues on the public agenda all over the world. Such visibility relates not only to the traditional functions of education, but it is mainly generated by the hope that education could (and will) improve the world. Enhanced expectations are balanced by stronger criticism towards educational systems. The economic

* Catalina ULRICH is an associate professor PhD at the Faculty of Psychology and Sciences of Education University of Bucharest. E-mail: catalina.ulrich@gmail.com 
analysis of education as a profitable investment on a long term, international testing efforts (including the use of benchmarks and indicators), evidence based policy design as well as paying attention to teachers as curriculum designers or key force for change represent just a few examples of nowadays issues regarding education. At the same time, post-structural or postmodern conceptualization of education brought into surface a strong criticism of the taken-for-granted canons regarding both fundamentals and practices of education.

Educational research represents an example of socially and politically embedded research fields within the humanities and social sciences, whose increasing accountability is generated by several aspects:

- Common principles that underlie science;

- More democratic approach and higher visibility of research related issues;

- Systematic concem to connect educational practice to research principles;

- Increasing preoccupation to make good use of the research in education in crafting policy alternatives;

- Ongoing efforts to provide funds and other resources for education research in a transparent and fairly manner;

- Institutional prestige as an inherent part of higher education, resulting in rankings that often become the rationale for resource allocation.

The focus on the knowledge society, as well as the educated person and emerging learning contexts are strongly connected to investment in enriching and refining the knowledge of education. When speaking about such knowledge, we have to bring into focus terms as type and quality. What does the knowledge about education mean nowadays? How is it developed? How influential is still the positivistic model of the natural sciences within the field of social sciences? How is it evaluated? Who benefits from such a body of knowledge? How are the scientific efforts supported? Starting with such preliminary questions, main aims of the article are the following:

- to identify and analyze main thematic areas in the field of education research for the last years;

- to examine recent trends in regard to research methodology approaches in Europe and United States;

- to use fresh insights and new dilemma in order to raise questions and provide suggestions regarding the redesign of doctoral programs curriculum for the psycho-pedagogical areas at the University of Bucharest. 


\section{Theoretical framework}

Shared working definitions and principles related to educational research. Despite the variety of epistemological or methodological approaches, there are working definitions taken for granted. We selected a couple of them. "Research is the orderly and systematic investigation of a phenomenon for the purpose of adding to knowledge" (Postlethwaite 2005: 7). Any research, whether exploratory or confirmatory or even descriptive, is framed to know/ answer/ solve something for which there does not exist any ready-made solution. Main purposes of social research include exploration, description and explanation. Education studies include more than one purpose. According to famous clarifications provided by Earl Babbie in the $12^{\text {th }}$ edition of his book The Practice of Social Research "exploration is the attempt to develop an initial, rough understanding of some phenomenon. Description is the precise measurement and reporting of the characteristics of some population or phenomenon under study. Explanation is to discover and reporting of relationships among different aspects of the phenomenon under study. Whereas descriptive studies answer the question what' so? Explanatory ones tend to answer the question why?" (Babbie 2010: 180).Another feature of educational research taken for granted is being unobtrusive research.

Legal definition of scientifically based research. Economic and political contexts generated the need to operate with a shared and agreed definition of scientifically based research. Grounded in scientific standards and principles, the following clarifications were made by AERA Council as a framework that offers sound guidance to members of Congress seeking to include such language in legislation (2008):

I. The term "principles of scientific research" means the use of rigorous, systematic, and objective methodologies to obtain reliable and valid knowledge. Specifically, such research requires:
(A) development of a logical, evidence-based chain of reasoning;
(B) methods appropriate to the questions posed;
(C) observational or experimental designs and instruments that provide reliable and generalizable findings;
(D) data and analysis adequate to support findings;
(E) explication of procedures and results clearly and in detail, including specification of the population to which the findings can be generalized;
(F) adherence to professional norms of peer review;
(G) dissemination of findings to contribute to scientific knowledge; and
(H) access to data for reanalysis, replication, and the opportunity to build on findings. 
II. The examination of causal questions requires experimental designs using random assignment or quasi-experimental or other designs that substantially reduce plausible competing explanations for the obtained results. These include, but are not limited to, longitudinal designs, case control methods, statistical matching, or time series analyses. This standard applies especially to studies evaluating the impacts of policies and programs on educational outcomes.

III. The term "scientifically based research" includes basic research, applied research, and evaluation research in which the rationale, design, and interpretation are developed in accordance with the scientific principles laid out above. The term applies to all mechanisms of federal research support, whether field-initiated or directed.

The European Expert Group on Assessment of University-Based Research provides the following comprehensive picture of research:

'New knowledge is no longer divided strictly between basic and applied activity but includes all research across the spectrum from curiosity-driven to user-led, from blue-sky to practice-based. It involves traditional and new disciplines, and qualitative, quantitative and practice-based methodologies. Research is increasingly conducted through participation in bi-lateral, inter-regional and global networks, involving mono-disciplinary, inter- and multi- and trans- disciplinary forms of inquiry and teams of researchers. Reflecting this complex, iterative and interactive process, new knowledge is disclosed in a wide variety of research outlets and outputs, from peer-reviewed articles to artefacts and prototypes, and including translations, software, encyclopaedia entries, research or technical reports, legal cases and maps". (Machkjewcz, W., Hazelkorn, E. \&Berghoff, S.,2010: 35)

Agreed definitions of educational research. In education, when people refer to research they may mean either empirical or non-empirical studies. Non-empirical studies could investigate the history of a practice, institution or individual, explore what a thinker or a number of thinkers have said about a specific topic, or use other written sources to compare educational practices in one country with those in another. Empirical research seeks information about something that can be observed in the real world or in the laboratory - what effect a certain kind of professional development has on a teacher's ability to teach, what impact socioeconomic factors have on student performance, whether a particular curriculum improves students' performance in mathematics, etc.

Another workable distinction within the field of education research relates to the types of data and research design. In quantitative research, the data are numbers and measurements; in qualitative research, the data are narrative descriptions and observations. Other differences are that qualitative research occurs in more natural and less controlled research settings than does 
quantitative research, and qualitative research often uses special methods to collect data, such as case study and ethnography. These methods reflect the philosophy of qualitative research, which emphasizes in-depth descriptions of persons, behaviours and contexts. With regard to research designs, correlational, experimental and quasi-experimental designs usually collect quantitative data. Simple descriptive and comparative descriptive designs collect either type of data. When both quantitative and qualitative data are collected in the same study, the approach is called mixed methods. The emergent mixed methods research is achieving increasing acceptance and use across disciplines. However, there are studies that demonstrate the need to enhance the dynamic relationship between researchers' decisions to propose mixed methods studies and existing extramural funding mechanisms, for health or education related research projects (Plano Clark 2010: 430). The requirements of funding bodies for mixed methods, regardless of any philosophical or theoretical commitments is regarded as "a kind of administrative pragmatism, aimed at producing some 'balanced' and 'credible' findings" (Johnson, Onwuegbuzie \& Turner 2007: 112). New generation researchers (trained in both quantitative and qualitative methods) overpass more and more the old and often antagonistic division between quantitative and qualitative. "For these scholars, research is problemdriven and not methodology-driven, meaning that those methods are employed that for a given problematic best help answer the research questions at hand." (Flyvbjerg 2011:313)

Classification of educational research studies. Another way of classifying educational research studies is to define the various types of research according to the kinds of information that they provide. Accordingly, UNESCO reference book written by Neville Postlethwaite (2005) Educational research: some basic concepts and terminology provides the following classification.

Historical research generates descriptions, and sometimes attempted explanations, of conditions, situations, and events that have occurred in the past (e.g. training programs in the past).

Descriptive research provides information about conditions, situations, and events that occur in the present (e.g. physical facilities of the school buildings).

Correlational research involves the search for relationships between variables through the use of various measures of statistical association (e.g. relationship between teachers' professional satisfaction and salaries, school and classroom supplies etc.)

Causal research aims to suggest causal linkages between variables by observing existing phenomena and then searching back through available data in order to try to identify plausible causal relationships (e.g. secondary school students 'drop out').

Experimental research is used in settings where variables defining one or more 'causes' can be manipulated in a systematic fashion in order to discem 'effects' on other variables (e.g. effectiveness of new software or textbooks 
using random assignment of teachers and students in control and experimental groups).

Case study research generally refers to two distinct research approaches. One means the in-depth study of a particular student, classroom, or school with the aim of producing a nuanced description of the pervading cultural setting that affects education, and an account of the interactions that take place between students and other relevant persons. The second approach to case study research requires the use of quantitative research methods to non-probability samples which provide results that are not necessarily designed to be generalizable to wider populations.

Ethnographic research usually consists of a description of events that occur within the life of a group - with particular reference to the interaction of individuals in the context of the sociocultural norms, rituals, and beliefs shared by the group. The researcher generally participates in some part of the normal life of the group and uses what he or she learns from this participation to understand the interactions between group members.

Development and evaluation research focuses on the interaction between research and the production and evaluation of a new product. Investigation of teachers' reactions to the various drafts and redrafts of a new mathematics teaching kit, with the information gathered at each stage being used to improve each stage of the drafting process means 'formative'. Alternatively, it can be 'summative' (by evaluating the worth of the final product, especially in comparison to some other competing product). For example, a comparison of the mathematics achievement of students exposed to a new mathematics teaching kit in comparison with students exposed to the established mathematics curriculum.(Postlethwaite 2005: 9-10)

Guiding principles for scientific research. According to US National Research Council publication, Scientific Research in Education, the scientific enterprise depends on a healthy community of researchers and is guided by a set of fundamental principles. Such principles "are not a set of rigid standards for conducting and evaluating individual studies, but rather are a set of norms enforced by the community of researchers that shape scientific understanding" (Shavelson \& Towne 2002: 16 ). Six guiding principles underlie all scientific inquiry, including education research: Pose significant questions that can be investigated empirically, link research to relevant theory, use methods that permit direct investigation of the question, provide a coherent and explicit chain of reasoning, replicate and generalize across studies, disclose research to encourage professional scrutiny and critique.

Besides these epistemological principles, nowadays there is a higher preoccupation to protect subjects. There are different institutions (e.g. the Institutional Review Board IRB in US) must evaluate the potential physical or psychological risk of research involving human subjects or the European Research Council's regulations regarding scrutinity on personal data protection. 
Educational research and causal analysis. At one hand, social research became interconnected with social policy agenda (e.g. requirements for evidence based policy formulation at the European Union level). At another hand, findings of social research became part of our daily life. Questions like 'what works?' assume that general principles can be translated from specific examples into other contexts. Effective policy research has to depend on the idea of a 'generative mechanism' or relationships of cause and effect (Schneider 2007: 13). Such an interest among educational leaders and policymakers lead to an increasing concern regarding the need for scientifically based evidence on which to base funding decisions for specific educational programs and practices. Better evidence for making decisions about what programs and practices do or do not work is needed. This need brings into focus causal questions. Do particular programs and practices improve educational attainment, student academic achievement or social development? Issues of causality are present in specialized fields of education research. However, explaining issues in terms of causesis problematic in education. Social phenomena tend to be multifaceted; causal analyses have to be developed by interpretation, which are linked to various context bounded variables and bias. More specifically, education research requires multiple disciplinary perspectives. Furthermore, conducting education research that involves studying humans (e.g., teachers, students, community members etc.) is govemed by the need to ensure ethical treatment of these participants. Finally, education research depends on its relationships with practice.

Educational research and educational practices phronesis. Causal explanations and analysis are very much connected to the rationalist ideal that research-based knowledge must be context-independent. Even when research provides a convincing causal explanation, it does not necessarily imply any prescription for policy. Bent Flyvbjerg demonstrates that there are ways of generalising, which do not depend on causal analysis and fit with the complexity of the educational field. "Predictive theories and universals cannot be found in the study of human affairs. Concrete case knowledge is therefore more valuable than the vain search for predictive theories and universals" concludes Flyvbjerg in a recent interview (Kirkeby 2011:304). With reference to Aristotle he distinguishes between three kinds of knowledge: episteme, techne and phronesis. Episteme is scientific knowledge, invariable in time and space. Research leading to episteme is carried out with analytical rationality, it concerns know why. Techne is the technical know how, it is concrete, variable and context-dependent. Phronesis goes beyond analytical, scientific knowledge (episteme) and beyond technical knowledge (techne). Phronesis develops principles experientially, setting them against empirical evidence, and it does not need to consider underlying mechanisms to be effective. Phronesis provides the basis for a critique of technocratic approaches, a rationale for action and a focus for the development of altemative methods and approaches. Such a 
perspective fits with both the educational research and the educational practice as phronesis. In his books Rationality and Power (1998)and Making Social Science Matter (2001) Flyvbjerg demonstrates that the dependence on phronesis cannot avoid all of the pitfalls associated with generalisation, but it is more flexible, and less presumptuous, than a causal approach.

\section{Data collection and analysis}

In order to reach the objectives, we mainly used content analysis and selected the following data sources: intemational conferences, professional joumals, research grants, international research networks, $\mathrm{PhD}$ thesis published and available online, publications of relevant associations providing regulations regarding research, other events within the academic community (e.g. forums, public debates SAGE Method-space, LinkedIn Groups etc.). Given the timeframe, for the purpose of this article we systematically used mainly first two data sources (see table 1.):

Table 1. Correspondence between the data sources and data analysis

\begin{tabular}{|l|l|l|l|l|}
\hline No & \multicolumn{1}{|c|}{$\begin{array}{c}\text { Data } \\
\text { sources }\end{array}$} & \multicolumn{1}{|c|}{ Access } & $\begin{array}{l}\text { Type of analysis } \\
\text { \& instruments }\end{array}$ & \multicolumn{1}{|c|}{ Results } \\
\hline 1 & $\begin{array}{l}\text { International } \\
\text { conferences } \\
\text { EERA, } \\
\text { AERA, } \\
\text { WERA }\end{array}$ & $\begin{array}{l}\text { Internet } \\
\text { Data bases }\end{array}$ & $\begin{array}{l}\text { Longitudinal } \\
\text { Frequency }\end{array}$ & $\begin{array}{l}\text { Thematic fields (TF) } \\
\text { Methodological } \\
\text { approaches (MA) }\end{array}$ \\
\hline 2 & $\begin{array}{l}\text { International } \\
\text { research } \\
\text { networks }\end{array}$ & $\begin{array}{l}\text { Internet } \\
\text { Data bases }\end{array}$ & $\begin{array}{l}\text { Longitudinal } \\
\text { Frequency } \\
\text { Matrix }\end{array}$ & $\begin{array}{l}\text { TF } \\
\text { MA }\end{array}$ \\
\hline 3 & $\begin{array}{l}\text { Research } \\
\text { grants }\end{array}$ & $\begin{array}{l}\text { Internet } \\
\text { Data bases }\end{array}$ & Idem & $\begin{array}{l}\text { TF } \\
\text { MA }\end{array}$ \\
\hline 4 & $\begin{array}{l}\text { Publications } \\
\text { (publishing } \\
\text { houses } \\
\text { reviews on } \\
\text { professional } \\
\text { joumals) }\end{array}$ & $\begin{array}{l}\text { Internet } \\
\text { Data bases } \\
\text { Publishing } \\
\text { houses } \\
\text { catalogues }\end{array}$ & Matrix & $\begin{array}{l}\text { Priorities } \\
\text { Research Points, Research } \\
\text { Arena, Class }\end{array}$ \\
\hline 5 & $\begin{array}{l}\text { Ph.D. thesis } \\
\text { Dibrary } \\
\text { Data bases }\end{array}$ & Matrix & $\begin{array}{l}\text { TF } \\
\text { MA }\end{array}$ \\
\hline 6 & $\begin{array}{l}\text { Other } \\
\text { scientific } \\
\text { events }\end{array}$ & $\begin{array}{l}\text { Intemet } \\
\text { Announce } \\
\text { ments } \\
\text { Awards }\end{array}$ & Matrix & Priorities \\
\hline
\end{tabular}

-The matrix will be used for further content analysis of data collected from professional journals, conference abstracts, grants reports. 
The initial analysis of various data generated a first conceptual level. For operational reasons this level can be organized on several main thematic areas, where different labels (table 2) represent most frequent crosscutting issues:

coverage: research focus on international level, on system (national) level, at the school level (micro) or classroom level;

visibility of the public issues: from policy to implementation, testing, assessment and quality insurance to issues to professional development, which includes more and more personal development issues;

practical approach: reflects the range from fundamental research to more applicative, including evaluative research and action research done by individuals or teams of practitioners;

problematic priorities: recent research includes, at the one hand, the entire lifespan, looking for early childhood development and learning and adult learning. Formal and informal contexts are scrutinized. On the other hand research approaches more and more different learning and educational contexts, like families, communities, schooling, post-compulsory education and training. Not only policies or processes, but also the environment, in a broader sense, includes virtual contexts (internet, online communities of practice, forums, visual media, social media etc.) as learning opportunities. Inclusive education represents another prime line issues on the educational research agenda, while new topics bring more and more attention (health education, sustainable development, but also music and dance as crucial activities in education nowadays);

methodological options: levels of integration vary from a mono-disciplinary to multi, inter and trans-disciplinary options within the education research.

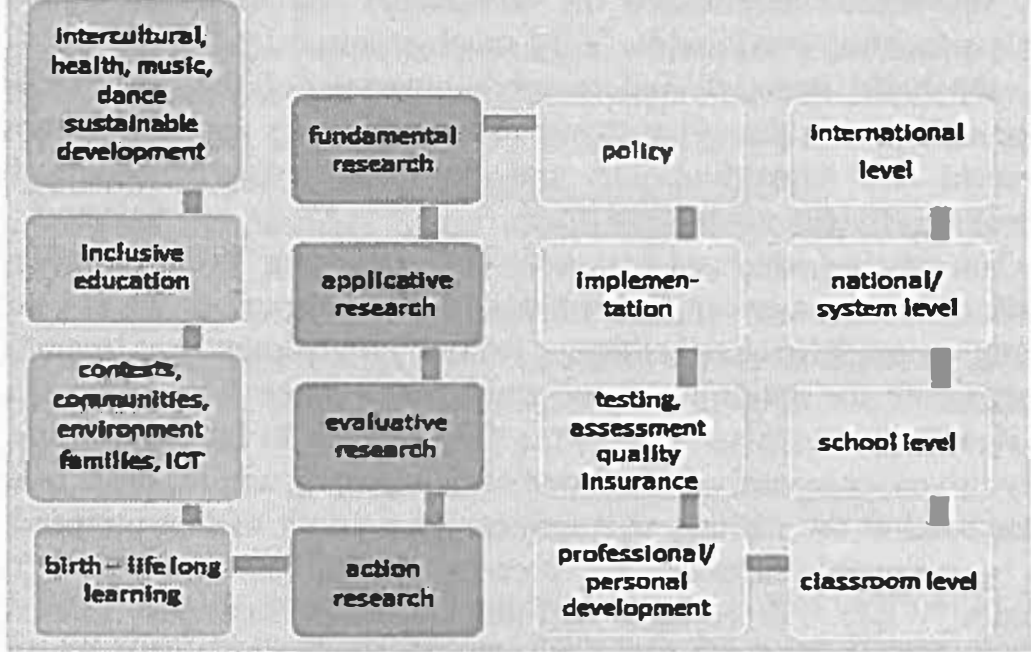

Figure 1. Main conceptual labels 
Briefly we can notice that the social, methodological and ethical aspects are more connected than in the past and traditional binary opposites in education research still are operational, but recent analysis brings into focus more relational aspects of both education and research and more complex conceptual models (see table 3).

Table 2. Binary opposites

\begin{tabular}{|c|c|c|}
\hline institutional accountability & \multirow{11}{*}{$\begin{array}{l}V \\
E \\
R \\
S \\
U \\
S\end{array}$} & $\begin{array}{l}\text { personal development (beliefs, emotions, } \\
\text { feelings) }\end{array}$ \\
\hline Individual & & Collective \\
\hline neutral, objective & & committed, responsible, civic driven \\
\hline international benchmarks & & auto biographic \\
\hline Statistics & & narrative materials \\
\hline $\begin{array}{l}\text { international assessments/ } \\
\text { testing }\end{array}$ & & digital ethnography \\
\hline communities of practice & & Identities \\
\hline migration & & $\begin{array}{l}\text { inclusive education, special needs, gender } \\
\text { issues, diversity }\end{array}$ \\
\hline Discrimination & & social justice \\
\hline \multirow[t]{2}{*}{ Multidisciplinary } & & inter-disciplinary \\
\hline & & trans-disciplinary \\
\hline
\end{tabular}

\section{Emerging trends in educational research}

The policy of research in universities (US and Europe).European research universities established the intellectual and academic traditions of university education world-wide. Very much inspired by French and German models, the basic structure and research purposes of the universities have remained constant. Although recognized as pioneering agents for knowledge development and innovation, US and European policy regarding funding research in universities varies very much.

The article University Research: Understanding Its Role (published by the Association of American Universities in 2011) describes the US policy of supporting research in universities. Federal govemment has maintained a partnership with the nation's research universities Since World War II relying on the bipartisan consensus that (1) the nation needs to invest its resources in curiosity-driven, competitively awarded basic research, and (2) basic research is best conducted at the nation's universities. As a result of that partnership, the federal government supports 60 percent of the research performed at universities. While U.S. colleges and universities perform just 13 percent of total national research and development (R\&D) funded by govermment and the private sector, they perform 56 percent of the nation's basic research, an element 
critical to the success of the overall enterprise. (http://0www.eric.ed.gov.novacat.nova.edu)

This fusion of education and cutting-edge research has been a unique feature of the U.S. university research system. The traditional European research model, for example, focuses research in special institutes that are not part of universities. Recent initiatives are meant to change the situation. The "knowledge triangle": research, education and innovation are three central and strongly interdependent drivers of the knowledge-based society*. In this respect, free movement of knowledge is supporting by research funding. The guidelines for granting warns the reader that "The process of grant writing and grant proposing is a somewhat delicate process for both the granter and the grantee: the granter wants to choose the research that best fits their scientific principles, and the grantee wants to apply for research in which she has the best chances but also in which she can build a body of work towards future scientific endeavours. This interplay can be a frustrating and lengthy process." (Eparvier 2010: 15). Such details bring into focus information relevant for our objectives, namely trends and valued methodological practices. For example, the same publication provides details about the most successful grant applications: "In particular, proposals of an interdisciplinary nature which cross the boundaries between different fields of research, pioneering proposals addressing new and emerging fields of research or proposals introducing unconventional, innovative approaches and scientific inventions are encouraged, as long as the expected impact on science, scholarship or engineering is significant." (idem). Also the idea of competition with US and Japan is explicit in many policy papers regarding research. For example, research teams from the EU and beyond can apply for the funds, "which are helping Europe to develop world-class research and close the innovation gap between the EU and its main competitors, the US and Japan. (...) To build up science and innovation, the EU wants to increase spending on research to $3 \%$ of gross domestic product by 2020 (from $2 \%$ in 2009). Achieving that target could create 3.7 million jobs and boost annual growth by about $€ 800 \mathrm{bn} . "$ (http://ec.europa.eu/news/science)

Most of EU Member States are putting a specific focus on human resources and on the linkages between the higher education sector and the private R\&D sector. CORDIS data and the already mentioned ERAWATCH Research Inventory Report show that concerning the research policy importance given by the Member states, one can identify three groups of countries. The

The ERAWATCH Research Inventory Report: OVERVIEW ACROSS EU COUNTRIES (2010) shows distribution of funding as following: Physical Sciences \& Engineering: 44\%, life Sciences: 39\%, social Sciences \& Humanities: $17 \%$. 
table below shows which member States give a high importance to research policy or give an increasing importance to research* (Eparvier 2010:20)

Table 3. Importance to research policy of EU member states

\begin{tabular}{|c|c|c|c|}
\hline $\begin{array}{c}\text { Polley } \\
\text { importance }\end{array}$ & Supported by allocation of ressource, other actions \\
\hline & \multicolumn{2}{|c|}{ INCREASING } \\
\hline UIOH & $\begin{array}{c}\text { Finland, Sweden, Spain, United Kingdom, Germany, } \\
\text { Denmark, Netherlands, Czech Republic, Slovakia } \\
\text { and Malta }\end{array}$ & Hungary, Italy and Latvia \\
\hline INCREASINO & $\begin{array}{c}\text { Luxembourg, Ireland, France, Cyprus, Estonia, } \\
\text { Romania and Portugal }\end{array}$ & $\begin{array}{c}\text { Lithuania, Slovenia, } \\
\text { Poland, Belgium and } \\
\text { Bulgaria }\end{array}$ \\
\hline LOW & Greece \\
\hline
\end{tabular}

A relevant comprehensive picture of the educational research at the European level (in comparison to international framework) is provided by the project European Educational Research Quality Indicators (EERQI 2008 2011).The overall goals of the project are to reinforce and enhance the visibility and competitiveness of European science and research via new approaches of assessing quality of research publications that are produced in the European research space. Traditional methods of assessing research quality of scientific publications depend heavily on ranking methods according to citation frequency and joumal impact factors $\dagger$. Such a tradition motivates the need of the project: this tradition was developed in the US; the methodologies were first applied on publication regarding (natural) sciences."Thus, the instruments are based on methodologies that neither reflect the research and publication traditions in the social sciences and humanities, nor do they show adequate coverage of European scientific publications. This is not least the case because European multilingualism is not covered in the respective methodologies. The vast majority of publications that are captured by the traditional instruments (such as ISI Thomson, Web of Science) are English media. The instruments do not take

* The only Member states which give a low importance to research policy is Greece (despite increased importance given to R\&D policy making and coordination), which could be also associated to the actual crisis.

$\dagger$ For example, readers can find as marketing strategy of European research joumals the following announcement: "We are pleased to announce that the European Journal of Education bas been awarded the following Impact Factor and ranking for 2010: Impact Factor: 0.194, ISI Journal Citation Reports Ranking: 2010: 154/177 (Education \& Educational Research). Even more, to celebrate the victory, editors offer a Special Issue for free. 
other than journal into account - no book publications, no publications in other media than print. Hence, if European science or institutions are exposed to these evaluation methods, not only individual researchers or institutions are ignored, but also complete subject domains and even language areas are disadvantaged. Specific features of European research publications are not - or only sparsely included in the traditional instruments."' (Gogolin 2011, http://www.eera.de)

Relevant educational research associations. We briefly presented the politics related to research in universities in Europe and US, as a broader context of educational research in universities. We are going to focus more specifically on the largest educational research associations which are relevant for dynamics of research in the field of education sciences (EERA, AERA, and WERA).

European Educational Research Association (EERA) was founded in June 1994 as a result of discussions among many national educational research associations and several major research institutes throughout Europe which identified the need for a European association to foster the exchange of ideas amongst European researchers, promote collaboration in research, improve research quality and offer independent advice on educational research to European policy-makers, administrators and practitioners. EERA membership is made up of more than 20 national and regional Educational Research Associations from all parts of Europe. EERA website presents the following purposes (www.eera.de):encouraging collaboration amongst educational researchers in Europe; promoting communication between educational researchers and international governmental organizations such as the EU, Council of Europe, OECD and UNESCO; improving communication amongst educational research associations and institutes within Europe; disseminating the findings of educational research and highlighting their contribution to policy and practice.

The American Educational Research Association (AERA), founded in 1916, is probably the oldest research association in the field of education. AERA website provides information about the mission, history, trends and resources for researchers and practitioners. "Concerned with improving the educational process by encouraging scholarly inquiry related to education and evaluation and by promoting the dissemination and practical application of research results" AERA is the most prominent international professional organization, with the primary goal of advancing educational research and its practical application. Its more than 25,000 members are educators; administrators; directors of research; persons working with testing or evaluation

\footnotetext{
* The project (2008 - 2011) is carried out by a Consortium of 19 Institutions, including two international and two national leamed societies in educational research, as well as departments of education at European universities, computer and documentation centers, and publishers of educational research (Gogolin, 2011)
} 
in federal, state and local agencies; counsellors; evaluators; graduate students; and behavioural scientists. The broad range of disciplines represented by the membership includes education, psychology, statistics, sociology, history, economics, philosophy, anthropology, and political science. (http://www.aera.net). AERA represents the largest and possibly the oldest education research group in the world. Both associations organize annual conferences (see table 5).

Table 4. EERA and AERA conferences 2000-20I1

\begin{tabular}{|c|c|c|}
\hline EERA conference theme & year & AERA conference theme \\
\hline Urban education & 2011 & $\begin{array}{l}\text { Inciting the Social } \\
\text { Imagination: Education Research for } \\
\text { the Public Good }\end{array}$ \\
\hline $\begin{array}{l}\text { Education and cultural } \\
\text { change }\end{array}$ & 2010 & $\begin{array}{l}\text { Understanding Complex Ecologies in } \\
\text { a Changing World }\end{array}$ \\
\hline $\begin{array}{l}\text { Theory and evidence in } \\
\text { European educational } \\
\text { research }\end{array}$ & 2009 & $\begin{array}{l}\text { Disciplined Inquiry: Education } \\
\text { Research in the Circle of Knowledge }\end{array}$ \\
\hline From teaching to leaming? & 2008 & $\begin{array}{l}\text { Research on Schools, } \\
\text { Neighbourhoods and Communities: } \\
\text { Toward Civic Responsibility }\end{array}$ \\
\hline $\begin{array}{l}\text { Contested qualities of } \\
\text { educational research }\end{array}$ & 2007 & The World of Educational Quality \\
\hline Transforming knowledge & 2006 & $\begin{array}{l}\text { Education Research in the Public } \\
\text { Interest }\end{array}$ \\
\hline $\begin{array}{l}\text { Vocational education and } \\
\text { training }\end{array}$ & 2005 & $\begin{array}{l}\text { Demography and Democracy in the } \\
\text { Era of Accountability }\end{array}$ \\
\hline $\begin{array}{l}\text { Current research in } \\
\text { vocational education and } \\
\text { training across Europe }\end{array}$ & 2004 & $\begin{array}{l}\text { Enhancing the Visibility and } \\
\text { Credibility of Educational Research }\end{array}$ \\
\hline $\begin{array}{l}\text { European Conference on } \\
\text { Educational Research }\end{array}$ & 2003 & $\begin{array}{l}\text { Accountability for Educational } \\
\text { Quality: Shared Responsibility }\end{array}$ \\
\hline $\begin{array}{l}\text { European Conference on } \\
\text { Educational Research }\end{array}$ & 2002 & $\begin{array}{l}\text { Validity and Value in Education } \\
\text { Research }\end{array}$ \\
\hline $\begin{array}{l}\text { Current research in } \\
\text { European vocational } \\
\text { education and human } \\
\text { resource development }\end{array}$ & 2001 & $\begin{array}{l}\text { What We Know and How We Know } \\
\text { It }\end{array}$ \\
\hline No information & 2000 & $\begin{array}{l}\text { Creating Knowledge in the 21st } \\
\text { Century: Insights From Multiple } \\
\text { Perspectives }\end{array}$ \\
\hline
\end{tabular}


The conference themes are also reflected into the dynamics of the research networks (table 6).

Table 5.Comparison of EERA thematic research networks 2002 and 2010

No. EERA Thematic Research Networks 2002

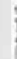

3 European Curriculum Research

4 Inclusive Education

5 Open and Distance Learning

6 Social Justice and Intercultural Education

7 Economics of Education

8 Student Assessment

9 Teacher Education Research

10 Quality Assurance and School Effectiveness

11 Information Centres and Libraries in Educational Research

12 Philosophy of Education

13 Communities and their Schools

14 Children and Youth at Risk and Urban Education

15 Research Partmerships in Education

16 ICT in Education and Training

17 History of Education

18 Comparative Education

19 Ethnography

20 Research in Innovative Intercultural Learning Environments
EERA Thematic Research Networks 2010

Continuing Professional Development.in Schools

Vocational Education \&

Trraining

Curriculum Innovation by

Schools and Teachers

Inclusive Education

Open Learning: Media, Environments and Cultures

Social Justice and Intercultural Education

Assessment, Evaluation, Testing and Measurement

Teacher Education Research

Educationsl Effectiveness and

Quality Assurance

LISnet - Library and Information

Science Network

Philosophy of Education

Communities, families, and schooling in educational research

Children and Youth at Risk and Urban Education

Research Partnerships in Education

ICT in Education and Training

Histories of Education

Closed

Ethnography

Research in Innovative Intercultural Learning Environments 


\section{Postgraduate Network}

22 Research in Higher Education
Emerging researchers

Research in Higher Education

23. Research on Children's

Rights in Education

24. Policy Studies and Politics of

Education

25. Mathematics Education

Research

26. Research on Health

Education

27. Research in Sport Pedagogy

28. Educational Leadership

29. Didactics - Learning and

Teaching

There are no major changes regarding main research networks. However, the changes of some networks' names indicate several issues. There are new major interests (e.g. various issues related to children, migration, environment, diversity), education is being approached in a wider sense than schooling, postmodernism reflected in multi-perspectivity, a greater focus on educators as reflective practitioners and new topics like health education and sports. Another comparison shows possible correspondence between the EERA and AERA major research networks. Since 1967, besides the main divisions, there are special interest groups (SIGs) within AERA, yearly updated. In 2010 there are 174 SIGs.

Table 6. EERA research networks and AERA divisions

\begin{tabular}{|l|l|}
\hline EERA research networks & AERA divisions \\
\hline $\begin{array}{l}\text { Professional development } \\
\text { VET NET }\end{array}$ & $\begin{array}{l}\text { Administration, Organization, \& } \\
\text { Leadership } \\
\text { Teaching \& Teacher Education } \\
\text { Education in the Professions }\end{array}$ \\
\hline Curriculum research & Curriculum Studies \\
\hline $\begin{array}{l}\text { Communities, families, and schooling in } \\
\text { educational research }\end{array}$ & Social Context of Education \\
\hline Inclusive education & Counselling \& Human Development \\
\hline $\begin{array}{l}\text { Open and Distance Learning } \\
\text { ICT in Education and Training }\end{array}$ & Learning \& Instruction \\
\hline History of Education & History \& Historiography \\
\hline $\begin{array}{l}\text { Educational Effectiveness and Quality } \\
\text { Assurance }\end{array}$ & $\begin{array}{l}\text { Educational Policy \& Politics } \\
\text { Research, Evaluation, \& Assessment in } \\
\text { Schools }\end{array}$ \\
\hline
\end{tabular}




\begin{tabular}{|l|l|}
\hline Research in Higher Education & Postsecondary Education \\
\hline Ethnography & $\begin{array}{l}\text { Measurement \& Research } \\
\text { Methodology }\end{array}$ \\
\hline $\begin{array}{l}\text { Social Justice and Intercultural Education } \\
\text { Research in Innovative Intercultural } \\
\text { Leaming Environments }\end{array}$ & $\begin{array}{l}\text { Diversity in Education\& Teacher } \\
\text { Education }\end{array}$ \\
\hline
\end{tabular}

There is a wide array of possibilities to analyze AERA's and EERA's websites. Firstly, the time gap is noticeable. Secondly, mission statements reflect major differences. More specifically, AERA states apragmatic, practice-oriented and socially committed vision, in comparison with EERA, that intends to be mainly a support framework for research bodies than a platform to nourish educational improvements and progress. Content analysis of the posted information on the web could be enriched also by other perspectives. For example, AERA has a more "humanistic" approach: the website has pictures of people involved in different committees, recorded speeches, links to video materials, as well as announcements regarding upcoming events and many awards and grants offered to students and practitioners. As a general message, AERA brings the idea that the work nurtures in practice and goes back to practice and to real people, providing useful links to professional joumals and also free publications. EERA provides less information in arather neutral way and the architecture of the site seems more administratively driven.

Another interesting research association should be taken into account in respect to methodological approaches, major thematic fields and policy options for educational research. Established in 2009, the World Education Research Association (WERA) is an association of national, regional, and international specialty research associations aimed at advancing education research as a scientific and scholarly field. "WERA aims to undertake initiatives that are global in nature and thus transcend what any one association can accomplish in its own country, region, or area of specialization. Member associations are resolved to work together to address such issues as building capacity and interest in education research, advancing education research policies and practices, and promoting the use and application of education research around the world." (www.weraonline.org) Amongst other ambitions, WERA is situated to promote and stimulate a world-wide perspective and is committed to doing so to promote excellence and inclusiveness in education research and thereby serve the public good around the world."The following list provides a sense of the range of research issues that will be considered for WERA Focal sessions in 2011: all topics are relevant to the broad theme of Imagination and Creativity - Wellsprings \& Streams of Education.

\begin{tabular}{|l|l|}
\hline 1. & The 21st Century Skills and Competencies \\
\hline 2. & Challenges and Opportunities in Student Assessment \\
\hline 3. & Social and Cultural Contexts of Teaching and Learning \\
\hline 4. & Social Inequality, Poverty, and Opportunities to Leam \\
\hline 5. & Diverse Populations, Education, and Learning \\
\hline 6. & Science Reasoning and Science Learning \\
\hline 7. & Mathematical Skills and Mathematics Education \\
\hline 8. & Language and Literacy \\
\hline
\end{tabular}




\begin{tabular}{|l|l|}
\hline 9. & New Technologies, Networks, and Leaming \\
\hline 10. & Human Development, Education, and Leaming \\
\hline 11. & Schools, Social Learning, and Citizenship \\
\hline 12. & Higher Education Assessment, Productivity, and Change \\
\hline 13. & Workforce and Adult Education \\
\hline 14. & Teacher Education and Professional Development \\
\hline 15. & Education Professions - Teachers, Faculty, and Education Leaders \\
\hline 16. & Education Indicators and Monitoring Education \\
\hline 17. & Education Change, Innovation, and Sustainability \\
\hline 18. & Research Related to Education Policy \\
\hline
\end{tabular}

We analyzed AERA (the oldest and largest US association), EERA (the largest European association) and WERA (the youngest but comprehensive association - as geographical coverage, with more than 60,000 researchers from six continents). Based on the initial dimensions of analysis (Table 2), using the content analysis of the information related to three research associations and corroborated to other data sources, we identified the following thematic strands and specific topics:

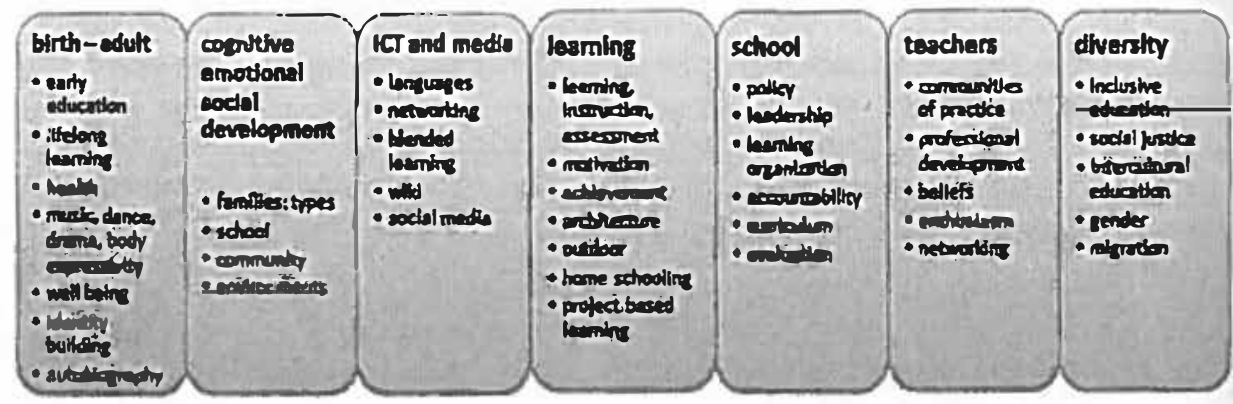

The picture is not comprehensive. However, it gives clues about the most common interests, recent substantive areas and sub-field specialties of education research.

\section{Conclusions}

Research in Europe is focused very much on the idea of research-driven or research-intensive university building the knowledge society.

Institutional prestige is an inherent part of higher education, resulting in rankings that often become the rationale for resource allocation. In this respect, educational research has a rather reactive position against US research accomplishment, under the pressure of intensifying effects of citation indices and university rankings worldwide.

Research topics cover major fields of traditional research, with emphasis on early education (even before birth), new leaming contexts, comprehensive approach of the learners (from physical, cognitive, emotional, 
social point of view) which draw substantially from neurosciences and educational psychology, such as cognitive development, knowledge structures, reasoning and problem solving, individual differences, emotional and social skills, self-confidence, self-regulation etc. There are also remarkable foci on sustainable development, sciences, new ICT and media environments, reflected in new instructional, assessment and architectural designs. Both teachers, learners, family members, professionals and community representatives are investigated either as individuals and part of social and professional networks or CoPs. Identity building and social networks are seen as multifaceted learning and development opportunities. Diversity and equity interconnect with already mainstreamed efforts for intercultural issues, special needs (new focus on $\mathrm{ADHD}$ and autistic spectrum), gender sensitivity and stronger impact of migration processes and increased economic disparities.

The actual range of conceptual and methodological framings in social sciences are more relational, system and practice-focused, reflected by intersections and fusion of sciences and approaches, mixed methodological approaches which combine randomized controlled experiments, analyses of large-scale datasets and also case studies, narratives, ethnography of digital media etc.). Unobtrusive, actual methodological frames work with a non-linear understanding of causality and embrace unpredictability in the world and undecidability in our understanding of it. (Fenwick, Edwards and Sawchuk 2011).The "special feature of small- $N$ research," (Ragin 1992: 225) complements analyses of large-scale samples and data with rigorous consistency, measures to insure reliability and validity (as triangulation, clarity of data analysis method) as well as for ethics and protection of subjects.

Concern for public accountability and intemational visibility of educational achievements of different systems (longitudinal studies, intemational benchmarking, multivariate statistical analysis) balances multiple perspectives of analysis, dialogue and humanistic approach, including concern toward understanding contexts and people's lives.

Doctoral students' experiences of scholarly communities involve different types of activities and skills, from examination of documents to empirical research, service to the institution, the discipline, profession and larger community. Given the complexity of the research community and research objects, universities should focus not only on scientific endeavour from a technical point of view, but more on ethical issues of research and social responsibility of scholars and educationalists. Such a framework would enrich both the research efforts as phronesis and educational endeavour, as reflective practice. 


\section{References}

1. BABBIE, E. R. (2010). The Practice of Social Research $12^{\text {th }}$ edition. Belmont: Wadsworth Cengage Learning

2. DENZIN N. \& LINCOLN, Y.S. (2011) The SAGE Handbook of qualitative research $4^{\text {th }}$ Edition (Thousand Oaks, CA: Sage).

3. EPARVIER, P. (2010). ERAWATCH Research Inventory Report: Overview across EU countries. http://cordis.europa.ew/erawatch

4. FLYVBERG, B. (2011). Case Study in Denzin, N \& Lincoln, Y. S. eds., The Sage Handbook of Qualitative Research, $4^{\text {th }}$ Edition. Thousand Oaks, CA: Sage.

5. FLYVBERG, B. (2001). Making social science matter: Why social inquiry fails and how it can succeed again. Cambridge, UK: Cambridge University Press.

6. JOHNSON, B. R., ONWUEGBUZIE, A. J. \& TURNER, L. (2007). Toward a Definition of Mixed Methods Research. Joumal of Mixed Methods Research. April 2007 vol. 1 no. 2. 112-133.

7. KIRKEBY, I. M. (2011). Transferable knowledge: an interview with Bent Flyvbjerg. arqvol 15. no 1.http://joumals.cambridge.org:

8. MACHKIEWCZ, W., HAZELKORN, E. \& BERGHOFF, S. (2010) Assessing Europe's University-Based Research Expert Group on Assessment of University-Based Research Brussels: Directorate-General for Research http://ec.europa.eu/research/era.

9. McALPINE, L., HORN, J \& RATH, J. (2011). Beyond teaching and research: inclusive understandings of academic practice. In Studies in Continuing Education. Vol. 33, No. 1.261-280

10. PLANO CLARK, V. L. (2010)-The Adoption and Practice of Mixed Methods: U.S. Trends in Federally Funded Health-Related Research". Qualitative Inquiry. vol. 16 no. 6.428-440.

11. POSTLETHWAITE, T. N. (2005). Educational research: some basic concepts and terminology International Institute for Educational Planning UNESCO Paris IIEP http://www.unesco.org/iiep.

12. SCHNEIDER, B., CARNOY, M., KILPATRICK, J., SCHMIDT, W. H., \& SHAVELSON, R. J. (2007). Estimating causal effects using experimental and observational designs Washington, DC: American Educational Research Association.

13. SHAVELSON, R. J \& TOWNE, L. (eds.). (2002). Scientific Research in Education Center for Education Division of Behavioural and Social Sciences and Education National Research. Council. Washington, DC: National Academy Press. http://www.nap.edu/openbook.php. 